\title{
Lymphatic compensation during the postoperative period after breast cancer treatment with axillary dissection
}

\section{Compensações linfáticas no pós-operatório de câncer de mama com dissecção axilar}

\author{
Mariana Maia Freire de Oliveira', Maria Teresa Pace do Amaral ${ }^{2}$, Maria Salete Costa Gurgel
}

\begin{abstract}
Lymphedema secondary to breast cancer causes physical and psychological morbidity and compromises quality of life. The objective of this literature review was to study lymphatic compensation after surgery for breast cancer and the factors that influence this process, with a view to understanding the etiopathogenesis of lymphedema. Articles indexed on Pubmed published from 1985 to 2012 were reviewed. According to the literature, lymphangiogenesis reduces damage to lymph vessels; there is little evidence that Vascular Endothelial Growth Factor is elevated in women with lymphedema; lymphovenous communications can be observed 60 days after surgery; women without lymphedema have acquired alternative mechanisms for removal of proteins from the interstitial space; and active exercise stimulates lymphatic and venous pumping. Health professionals should teach these patients about the risk factors for lymphedema. The effects of lymphangiogenesis, proteolysis and lymphovenous communications on development of lymphedema should be studied, since these events are intimately related.
\end{abstract}

Keywords: lymphatic system; lymphedema; breast cancer.

\begin{abstract}
Resumo
Linfedema secundário ao câncer de mama resulta em morbidade física e psicológica, e compromete a qualidade de vida. O objetivo desta revisão da literatura foi estudar as compensações linfáticas após cirurgia para câncer de mama e os fatores que interferem neste processo, visando a compreender a etiopatogenia do linfedema. Foram incluídos artigos publicados de 1985 a 2012, da base de dados Pubmed. Segundo a literatura, a linfangiogênese reduz danos nos vasos linfáticos; há pouca evidência de que o fator de crescimento vascular endotelial linfático é aumentado nas mulheres com linfedema; anastomoses linfovenosas são observadas 60 dias após a cirurgia; mulheres sem linfedema adquiriram mecanismos alternativos para remoção das proteínas do interstício, e exercício ativo estimula bombeamento linfático e venoso. Orientações dos fatores de risco para linfedema devem ser empregadas por profissionais da saúde. O efeito de linfangiogênese, proteólise e anastomoses linfovenosas sobre o desenvolvimento do linfedema deve ser estudado, pois são eventos intimamente relacionados.
\end{abstract}

Palavras-chave: sistema linfático; linfedema; câncer de mama. 


\section{INTRODUCTION}

The incidence of lymphedema after treatment for breast cancer varies from 2.4 to $56 \%{ }^{1}{ }^{1}$ Prevalence is estimated at $49 \%$, when patient-reported symptoms are included. ${ }^{2}$ The majority of cases have onset within 18 months of treatment ${ }^{3}$ and the condition can provoke considerable functional and psychological compromise.

Etiopathogenesis of lymphedema has its origins in a quantitative imbalance between the volume of lymph produced and the transport capacity of the lymphatic system (LS), and the condition can emerge with minimal or even zero damage to axillary lymph nodes. ${ }^{4,5}$ However, the imbalance itself has not been fully elucidated. ${ }^{6}$ It is however known that if normal production of lymph is greater than the capacity to transport it, then lymphedema will form ${ }^{4-6}$ and that some patients are predisposed to development of the condition because of previously ineffective lymphatic function in the as yet unaffected limb. ${ }^{6}$ Among women treated for breast cancer, factors that have been related to the development of lymphedema include: axillary radiotherapy, ${ }^{7}$ age, number of lymph nodes dissected and neoplasm with confirmed malignancy, which Berg levels are Berg dissected, ${ }^{7}$ obesity, surgical technique and infection. ${ }^{8,9}$

Axillary dissection can interrupt lymphatic flow, causing increased hydrostatic pressure against the vessel walls, which dilate, separating their lymphatic valves and allowing lymph reflux. ${ }^{10}$ Sentinel lymph node biopsy reduces the incidence of lymphedema, which is approximately $17 \%$ at 12-month follow-up. ${ }^{11}$

Studies designed to provide an understanding of the pathophysiology of lymphedema and to investigate methods of preventing it have investigated factors associated with regeneration of lymphatic function, such as lymphangiogenesis ${ }^{6,12}$; Vascular Endothelial Growth Factor $^{13}$; lympholymphatic anastomoses ${ }^{14-17}$; removal of interstitial protein, ${ }^{16,17}$ and physiotherapy techniques used during the postoperative period after breast cancer treatment, such as manual lymph drainage (MLD) ${ }^{18,19}$ and exercise. ${ }^{10,20}$

The objective of this study is describe the process of lymphatic tissue recuperation during the postoperative period after breast cancer treatment and the factors that influence this process.

\section{METHODS}

A literature review was conducted based on the results of a search of the PubMed database (http://www.ncbi.nlm.nih.gov/sites/entrez/) using the following keywords: breast cancer, lymphedema, lymphangiogenesis, vascular endothelial growth factor $C$, lymphovenous communications, protein transport / proteolysis, physiotherapy, exercise, manual lymphatic drainage. Only articles published between 1985 and 2012 were reviewed.

Articles were chosen by accessibility, considering studies that covered the behavior of the LS during the postoperative period after breast cancer treatment and studies that described the influence of physiotherapy techniques used during the postoperative period. Studies published in English were selected and additional references, such as studies cited in the articles found by the database search, were also reviewed.

\section{RESULTS}

A total of 27 articles were selected for review. After reading the full texts of these studies, 12 were selected. Nine studied women treated surgically for breast cancer, two employed animal models and one is a review article. The results are summarized descriptively in Table 1, listing the variables studied, the techniques employed and the results reported.

The following information relating to the keywords employed was extracted from the literature.

Lymphangiogenesis: attenuates the damage to lymph vessels caused by axillary dissections ${ }^{12}$ and in many cases the transport capacity of the new vessels thus formed can be sufficient to prevent lymphedema. ${ }^{6}$

Vascular Endothelial Growth Factor C (VEGF-C): lymphatic regeneration and VEGF-C are regulated by the presence or absence of interstitial tissue flow. Lymphatic insufficiency causes a reduction in the velocity of fluids flowing into the LS and this state is detected in the interstitial cells, probably by fibroblasts, which trigger an increase in VEGF-C production. ${ }^{6}$ This factor stimulates lymphangiogenesis, lymphatic contractions and increased lymphatic flow. ${ }^{6}$

However, in low flow rate states, rather than acting on the LS, VEGF-C acts on the blood vessels, increasing fluid filtration. The increased interstitial flow restores tissue pressure, but at the cost of increased volume, which in turn increases lymph flow to the lymph vessels, which causes a reduction in VEGF-C secretion. If this state is once more changed because of lymphatic insufficiency, VEGF-C will be produced again and the cycle will repeat until equilibrium is restored. ${ }^{6}$

A study employing an animal model of lymphedema found that treatment with VEGF-C reversed edema 
Table 1. Studies of the repercussions of dissection of lymph nodes for lymphatic compensation.

\begin{tabular}{|c|c|c|c|}
\hline Authors & Sample & Variables Analyzed & Results \\
\hline Stanton et al. ${ }^{21}$ & $\begin{array}{l}14 \text { healthy women and } 22 \\
\text { with axillary dissection }\end{array}$ & $\begin{array}{l}\text { Capacity and degree of microvascular } \\
\text { filtration in upper limbs (operated } \times \\
\text { contralateral) }\end{array}$ & $\begin{array}{l}\text { There was no significant difference between } \\
\text { upper limbs }\end{array}$ \\
\hline Box et al. ${ }^{22}$ & $65^{*}$ & Exercise and guidance $+\times$ guidance & $\begin{array}{l}\text { Exercises reduce the incidence of lymph- } \\
\text { edema and change its course }\end{array}$ \\
\hline Yoon et al..$^{23}$ & Animal model & VEGF-C & $\begin{array}{l}\text { Stimulates lymphangiogenesis and reverses } \\
\text { edema }\end{array}$ \\
\hline Lane et al. ${ }^{12}$ & $16^{*}$ & Resistance exercises and aerobic exercises & Do not increase risk of lymphedema \\
\hline Pain et al. ${ }^{16}$ & $16^{*}$ & Clearance of proteins from blood & $\begin{array}{l}\text { Removed by lympholymphatic communi- } \\
\text { cations or enzymatic degradation }\end{array}$ \\
\hline Ahmed et al..$^{24}$ & $45^{*}$ & Resistance exercises $\times$ control & $\begin{array}{l}\text { Did not increase risk and did not exacer- } \\
\text { bate symptoms of lymphedema }\end{array}$ \\
\hline Modi et al. ${ }^{15}$ & Review & Lymphovenous communications & Alternative route for lymphatic drainage \\
\hline Sagen et al..$^{21}$ & $204^{*}$ & $\begin{array}{l}\text { Three groups: restricted activities; no re- } \\
\text { strictions; moderate resistance exercises }\end{array}$ & $\begin{array}{l}\text { Women should be encouraged to continue } \\
\text { their activities without restrictions }\end{array}$ \\
\hline Sarri et al. ${ }^{26}$ & $22^{*}$ & Manual lymph drainage & $\begin{array}{l}\text { Associated with significant difference in } \\
\text { radiopharmaceutical progression }\end{array}$ \\
\hline Lacomba et al. ${ }^{27}$ & $160^{*}$ & $\begin{array}{l}\text { Educational strategies } \times M L D+\text { Exercises }+ \\
\text { Educational strategies }\end{array}$ & $\begin{array}{l}\text { Lower incidence of lymphedema in women } \\
\text { given MLD }\end{array}$ \\
\hline Bates et al. ${ }^{6}$ & Sheep & Lymphangiogenesis and VEGF-C & $\begin{array}{l}\text { Prevents clinical manifestations of } \\
\text { lymphedema. Increased capillary hydraulic } \\
\text { resistance }\end{array}$ \\
\hline Devoogdt et al. ${ }^{28}$ & $160^{*}$ & Exercises $\times$ Exercises + MLD & $\begin{array}{l}\text { Addition of MLD did not have an effect on } \\
\text { reduction of lymphedema incidence }\end{array}$ \\
\hline
\end{tabular}

*Women treated surgically for breast cancer.

through lymphangiogenesis. ${ }^{23}$ However, there is as yet little evidence that VEGF-C is elevated in women who exhibit lymphedema after mastectomy. ${ }^{23}$

Lymphovenous communications: one possible route for lymph to reach the veins, ${ }^{14}$ which has been observed in humans and in animal models. ${ }^{16,17}$ After LS injury, it develops a continuation of the venous endothelium, with subsequent regression of all lymphovenous communications, except for those in the neck. If any anastomoses remain in the adult upper limb, they become functional after the normal lymphatic drainage route is blocked. ${ }^{15}$

A study conducted with lymphoscintigraphy of 37 women before surgery and during the postoperative period after breast cancer treatment with axillary dissection observed significant changes, such as dermal backflow and compromise to both velocity and intensity of uptake the radiopharmaceutical, demonstrating functional differences in the upper limb LS. ${ }^{14}$ Additionally, the study also showed that changes to lymphatic drainage can be detected within 60 days of surgery, as can the presence of lymphovenous communications. ${ }^{14}$

Protein transport: macromolecular transport between blood vessels and the interstitial space predominantly occurs by convection and, in normal situations, is not significant. However, after surgery this transport may pass through the anatomic peripheral lymphovenous communications that open, or directly through the venous capillary endothelium, possibly provoked by the increase in interstitial pressure resulting from the surgical trauma. It can also be facilitated by enzymatic degradation of proteins into fragments with greater diffusibility. ${ }^{16}$

It is possible that women who do not develop lymphedema after surgery for breast cancer possibly develop alternative routes for removal of proteins from the interstitial space in the upper limbs, which may be anatomic (lympholymphatic or lymphovenous communications distal to lymph node dissection $)^{16}$ and/or functional (increase in protein transport by local blood vessels). ${ }^{16,17}$

Physiotherapy rehabilitation techniques: studies have demonstrated the effectiveness of rehabilitation of patients after surgery for breast cancer, ${ }^{29-31}$ and prevention of lymphedema is one of the objectives. Myolymphokinetic exercises and manual lymph drainage (MLD) are among the most studied modalities. ${ }^{26,29-31}$

Manual lymph drainage is indicated during the postoperative period after breast cancer treatment, because it increases lymphatic flow without increasing capillary filtration. ${ }^{18}$ Its physiological effects include increased contraction of lymphangions, ${ }^{19}$ increased absorption of proteins by lymphatic capillaries, ${ }^{20}$ 
reduced microlymphatic hypertension ${ }^{32}$ and improved collateral lymphatic drainage between the lymphatic regions of the skin, ${ }^{33}$ without increasing risk of metastases. Lymphoscintigraphy of the upper limbs of women operated on for breast cancer was able to show that the technique promotes greater absorption of the radiopharmaceutical in lymph nodes that were visible before MLD and also showed other lymph nodes that had not been visible before MLD. ${ }^{26}$ As a result, the therapy prevents the limb's circumference from increasing. ${ }^{32}$

Myolymphokinetic exercises stimulate musculoskeletal contractions, which are the primary pumping mechanism for lymphatic and venous drainage ${ }^{10}$; "re-set" the interaction between sympathetic nervous system and the lymph vessels, stimulating contraction ${ }^{10}$; increase capillary density in the muscle bed ${ }^{34}$ and stimulate lymphangiogenesis around the axillary lymphatic damage,$^{20}$ which in turn aids in lymphatic formation and propulsion, ${ }^{12}$ thereby contributing to prevention of lymphedema over the long term. ${ }^{10}$ However, one study using lymphoscintigraphy did not support the hypothesis that these exercises result in increased lymphatic drainage. ${ }^{34}$

\section{DISCUSSION}

The majority of women who are treated with axillary dissection do not develop lymphedema ${ }^{16}$; but the mechanisms of lymphatic compensation are not fully understood. It has been suggested that opening of anatomic lymphovenous communications in the upper limbs, that redirect the lymph across lympholymphatic communications distal of lymph node dissection, and increase in tissue proteolysis mediated by macrophages,${ }^{16}$ may be mechanisms that compensate for damage to the LS, preventing lymphatic stasis in the upper limb ipsilateral to surgery.

In the cadaver of a patient who had been treated surgically for breast cancer 11 years previously, abnormal patterns of superficial lymphatic drainage were observed in the lymphedema-free upper limb ipsilateral to surgery, in comparison to the contralateral limb. The abnormal patterns observed were: curtailed vessels with flow diverted at frequent intervals; dermal backflow; opening of canals between superficial collectors and between the superficial and deep systems; LS atrophy; benign expansion of lymph nodes in the upper limb, and lymphovenous communications. The authors linked the absence of lymphedema to the effectiveness of the deep LS, to the presence of some residual axillary lymph nodes, the presence of communication between the superficial and deep systems, and to the presence of interconnections between the superficial collectors. ${ }^{35}$ However, a study conducted by Batse et al. raised the hypothesis that the lymphoscintigraphic characteristics observed in post-mastectomy lymphedema - such as dilation of vessels and leakage and dermal backflow - can also be observed in the upper limbs of women without lymphedema ${ }^{6}$ thus suggesting that these adaptations would not be sufficient to prevent lymphedema.

Pain et al. ${ }^{16}$ followed 16 women treated surgically for breast cancer for 3 years and related a reduced tendency to develop lymphedema to increased mobilization of protein injected into the subcutaneous space, either via the vascular endothelium or via new lymphovenous communications. However, they considered further studies were necessary to confirm their findings. ${ }^{16}$

Opening of lympholymphatic communications can be prejudiced by an ineffective healing process, by formation of seroma, by radiotherapy and by inadequate early exercise. ${ }^{13,14}$ Restoration of lymphatic flow is benefited by the following conditions: an effective healing process, immobilization of the shoulder ipsilateral to surgery, MLD, myolymphokinetic exercises and less aggressive surgery. ${ }^{14}$

Physiotherapy has a fundamental role to play in prevention, early detection and treatment of lymphedema secondary to breast cancer, ${ }^{29-31,36}$ and has been adopted as routine at centers of excellence. ${ }^{30,31}$ Studies demonstrate that recovery or maintenance of shoulder mobility is based on mobility and stretching exercises, ${ }^{36}$ and suggest that early intervention does not increase complications, such as infections, wound healing disorders or lymphedema. ${ }^{36,37}$

A low incidence of lymphedema was observed among women who exercised regularly, who were given preoperative patient education and who adhered to selfcare. ${ }^{30}$ The repercussions of early exercise on formation of new vessels is still under debate. ${ }^{37} \mathrm{It}$ is believed that regular exercise stimulates lymphangiogenesis and that it could reduce the damage caused by dissection and by axillary radiotherapy. ${ }^{20}$ Lymphoscintigraphy results from women treated for breast cancer with clinically normal limbs were occasionally abnormal, showing delayed lymphatic drainage because of ineffective lymph vessel contraction. ${ }^{20}$ Notwithstanding, 2 minutes of exercises normalized lymphatic pressure, accelerating lymph drainage and, in some cases, the results showed evidence of mechanisms compensating for lymphedema. ${ }^{38}$

When sheep with intact LS were subjected to short duration exercises, increased frequency of contractions and increased lymphatic flow were observed, compared to baseline values. ${ }^{39}$ Exercise provokes increases in 
arterial blood pressure and cardiac output, resulting in increased capillary filtration, which in turn raises interstitial pressure, promoting entry of liquid and proteins into lymphatic capillaries. However, there was no correlation between propulsion of fluids and normal movements in isolated prepared tissues. ${ }^{12,39}$ Other authors have observed that during exercise both mechanisms, intrinsic and extrinsic, are augmented, increasing propulsion of lymph through the lymph vessels. ${ }^{12,15}$

Irrespective of what happens to the lymph vessels, the positive impact of exercise on muscular and cardiovascular systems appears to promote removal of lymph from defective lymphatic transport systems, including the effect of the muscle pump on venous flow and, probably, lymphatic flow. ${ }^{34}$

A randomized study investigating 22 women during the postoperative period after breast cancer treatment detected the effects of MLD using lymphoscintigraphy. Twelve of the women were given MLD. All 22 women were examined with upper limb lymphoscintigraphy on two different occasions, before and after MLD. The effectiveness of MLD was demonstrated by significant differences in radiopharmaceutical progression. The authors therefore considered that this resource could be indicated as a preventative measure to avert development of lymphedema. ${ }^{37}$ This position is supported by findings published by Lacomba, who observed that MLD had an effect on lymphatic circulation, especially subcutaneous circulation, and on initial lymphatic capillaries, with respect to interstitial fluid removal, and concluded that early physiotherapy was effective for prevention of lymphedema for at least the first year after surgery. ${ }^{27}$

Since MLD maneuvers divert lymphatic flow in a direction that is different from the normal direction, they thereby stimulate an alternative drainage route. ${ }^{26}$ Considering that inflammation secondary to the surgical insult interferes with lymphatic drainage and provokes increased limb volume, protein stagnation in the interstitial space and risks of complications, the results of these studies emphasize the need to stimulate lymphatic drainage early on. Self-drainage is a technique that is easy for patients to perform and health professionals involved in rehabilitation can instruct them in the technique. ${ }^{26}$

Therefore, health professionals should teach patients how to care for their upper limbs and about the risk factors for lymphedema that have been identified to date, and also how to use those techniques for preventing and treating the disease that are already established in the literature.

Study of the LS is an emerging field of research. ${ }^{37}$ Over recent years, development and validation of new culturing systems and new in vivo models have contributed to a rapid expansion of knowledge about the mechanisms of lymphatic development and the diseases associated with lymphatic dysfunction. ${ }^{40}$ However, the effects of lymphangiogenesis, of extralymphatic proteolysis and lymphovenous communications on development of lymphedema are questions that merit further discussion and about which more information is needed, since these events are intimately related.

\section{CONCLUSIONS}

The process through which lymphatic tissues recuperate during the postoperative period after breast cancer treatment and development of lymphedema are subjects that merit further discussion and about which more information is needed, since the two events are intimately related. The findings of this review suggest that teaching patients about the risk factors for lymphedema that have been identified to date is an essential strategy that health professionals should employ.

\section{REFERENCES}

1. Preston NJ, Seers K, Mortimer PS. Physical therapies for reducing and controlling lymphoedema of the limbs. Cochrane Database Syst Rev. 2009; (1).

2. Petrek JA, Senie RT, Peters M, Rosen PP. Lymphedema in a cohort of breast carcinoma survivors 20 years after diagnosis. Cancer. 2001;92(6):1368-77. http://dx.doi.org/10.1002/10970142(20010915)92:6<1368::AID-CNCR1459>3.0.CO;2-9. PMid:11745212

3. Clark B, Sitzia J, Harlow W. Incidence and risk of arm oedema following treatment for breast cancer: a three-year follow-up study. QJM. 2005;98(5):343-8. http://dx.doi.org/10.1093/qjmed/ hci053. PMid:15820971

4. Stanton AWB, Modi S, Mellor RH, et al. A quantitative lymphoscintigraphic evaluation of lymphatic function in the swollen hands of women with lymphoedema following breast cancer treatment. Clin Sci. 2006;110(5):553-61. http://dx.doi. org/10.1042/CS20050277. PMid:16343054

5. Kim C, Li B, Papaiconomou C, Zakharov A, Johnston M. Functional impact of lymphangiogenesis on fluid transport after lymph node excision. Lymphology. 2003;36(3):111-9. PMid:14552030.

6. Bates DO. An interstitial hypothesis for breast cancer related lymphoedema. Pathophysiology. 2010;17(4):289-94. http://dx.doi. org/10.1016/j.pathophys.2009.10.006. PMid:19963358

7. Tsai RJ, Dennis LK, Lynch CF, Snetselaar LG, Zamba GKD, ScottConner C. The risk of developing arm lymphedema among breast cancer survivors: a meta-analysis of treatment factors. Ann Surg Oncol. 2009;16(7):1959-72. http://dx.doi.org/10.1245/s10434009-0452-2. PMid:19365624

8. Warren AG, Brorson H, Borud LJ, Slavin SA. Lymphedema: a comprehensive review. Ann Plast Surg. 2007;59(4):464-72. http:// dx.doi.org/10.1097/01.sap.0000257149.42922.7e. PMid:17901744

9. Hayes SC, Janda M, Cornish B, Battistutta D, Newman B. Lymphedema after breast cancer: incidence, risk factors, and effect on upper body function. J Clin Oncol. 2008;26(21):3536-42. http://dx.doi. org/10.1200/JCO.2007.14.4899. PMid:18640935 
10. Bicego D, Brown K, Ruddick M, Storey D, Wong C, Harris SR. Exercise for women with or at risk for breast cancer-related lymphedema. Phys Ther. 2006;86(10):1398-405. http://dx.doi. org/10.2522/ptj.20050328. PMid:17012644

11. Francis WP, Abghari P, Du W, Rymal C, Suna M, Kosir MA. Improving surgical outcomes: standardizing the reporting of incidence and severity of acute lymphedema after sentinel lymph node biopsy and axillary lymph node dissection. Am J Surg. 2006;192(5):636-9. http://dx.doi.org/10.1016/j.amjsurg.2006.08.018. PMid:17071198

12. Lane K, Worsley D, Mckenzie D. Exercise and the lymphatic system: implications for breast-cancer survivors. Sport Med. 2005 35(6):461-71.

13. Stanton AW, Modi S, Bennett Britton TM, et al. Lymphatic drainage in the muscle and subcutis of the arm after breast cancer treatment. Breast Cancer Res Treat. 2009;117(3):549-57. http:// dx.doi.org/10.1007/s10549-008-0259-z. PMid:19052859

14. Rezende LF, Pedras FV, Ramos CD, Gurgel MSC. Evaluation of lymphatic compensation by lymphoscintigraphy in the postoperative period of breast cancer surgery with axillary dissection. Tumori. 2011;97(3):309-15. PMid:21789008.

15. Modi S, Stanton AWB, Mortimer PS, Levick JR. Clinical assessment of human lymph flow using removal rate constants of interstitial macromolecules: a critical review of lymphoscintigraphy. Lymphat Res Biol. 2007;5(3):183-202. http://dx.doi.org/10.1089//rb.2007.5306. PMid:18035937

16. Pain SJ, Barber RW, Solanki CK, et al. Short-term effects of axillary lymph node clearance surgery on lymphatic physiology of the arm in breast cancer. J Appl Physiol. 2005;99(6):2345-51. http:// dx.doi.org/10.1152/japplphysiol.00372.2005. PMid:16288099

17. Jila A, Kim H, Nguyen VPKH, et al. Lymphangiogenesis following obstruction of large postnodal lymphatics in sheep. Microvasc Res. 2007;73(3):214-23. http://dx.doi.org/10.1016/j.mvr.2006.11.003. PMid:17188720

18. Hutzschenreuter P, Brümmer H, Ebberfeld K. [Experimental and clinical studies of the mechanism of effect of manual lymph drainage therapy]. Z Lymphol. 1989;13(1):62-4. PMid:2672666.

19. Leduc $O$, Bourgeois A. Bandages: scintigraphic demonstration of its efficacy on colloidal protein reabsorption during muscle activity. In: International Congress of Lymphology; 1989. Amsterdam: Elsevier; 1990. p. 421-3.

20. Lane KN, Dolan LB, Worsley D, McKenzie DC. Upper extremity lymphatic function at rest and during exercise in breast cancer survivors with and without lymphedema compared with healthy controls. J Appl Physiol. 2007;103(3):917-25. http://dx.doi. org/10.1152/japplphysiol.00077.2007. PMid:17585046

21. Stanton AW, Holroyd B, Mortimer PS, Levick JR. Comparison of microvascular filtration in human arms with and without postmastectomy oedema. Exp Physiol. 1999;84(2):405-19.

22. Box RC, Reul-Hirche HM, Bullock-Saxton JE, Furnival CM. Physiotherapy after breast cancer surgery: results of a randomised controlled study to minimise lymphoedema. Breast Cancer Res Treat. 2002;75(1):51-64.

23. Yoon YS, Murayama T, Gravereaux E, et al. VEGF-C gene therapy augments postnatal lymphangiogenesis and ameliorates secondary lymphedema. J Clin Invest. 2003;111(5):717-25. http://dx.doi. org/10.1172/JCl15830. PMid:12618526

24. Ahmed RL, Thomas W, Yee D, Schmitz KH. Randomized controlled trial of weight training and lymphedema in breast cancer survivors. J Clin Oncol. 2006; 24(18):2765-72.

25. Sagen A, Kåresen R, Risberg MA. Physical activity for the affected limb and arm lymphedema after breast cancer surgery. A prospective, randomized controlled trial with two years follow-up. Acta Oncol. 2009;48(8):1102-10. http://dx.doi.org/10.3109/02841860903061683.
26. Sarri AJ, Moriguchi SM, Dias R, et al. Physiotherapeutic stimulation: early prevention of lymphedema following axillary lymph node dissection for breast cancer treatment. Exp Ther Med. 2010 1:147-52.

27. Torres Lacomba M, Yuste Sánchez MJ, Zapico Goñi A, et al. Effectiveness of early physiotherapy to prevent lymphoedema after surgery for breast cancer: randomised, single blinded, clinica trial. BMJ. 2010;340(1):b5396. http://dx.doi.org/10.1136/bmj.b5396. PMid:20068255

28. Devoogdt N, Christiaens MR, Geraerts I, et al. Effect of manual lymph drainage in addition to guidelines and exercise therapy on arm lymphoedema related to breast cancer: randomised controlled trial. BMJ. 2011;343:d5326.

29. van der Horst CMAM, Kenter JAL, de Jong MT, Keeman JN. Shoulder function following early mobilization of the shoulder after mastectomy and axillary dissection. Neth J Surg. 1985;37(4):105-8 PMid:3900809.

30. de Rezende LF, Franco RL, de Rezende MF, Beletti PO, Morais SS, Gurgel MS. Two exercise schemes in postoperative breast cancer: comparison of effects on shoulder movement and lymphatic disturbance. Tumori. 2006;92(1):55-61. PMid:16683384.

31. Oliveira MMF, Gurgel MSC, Miranda MS, Okubo MA, Feijó LFA, Souza GA. Efficacy of shoulder exercise on locoregiona complications in women undergoing radiotherapy for breast cancer: clinical Trial. Braz J Phys Ther. 2009;13(2):136-44. http:// dx.doi.org/10.1590/S1413-35552009005000017.

32. Williams AF, Vadgama A, Franks PJ, Mortimer PS. A randomized controlled crossover study of manual lymphatic drainage therapy in women with breast cancer-related lymphoedema. Eur J Cancer Care (Engl). 2002;11(4):254-61. http://dx.doi.org/10.1046/j.1365 2354.2002.00312.x. PMid:12492462

33. Cheifetz O, Haley L, Breast Cancer Action. Management of secondary lymphedema related to breast cancer. Can Fam Physician. 2010;56(12):1277-84. PMid:21375063.

34. Schmitz KH, Troxel AB, Cheville A, et al. Physical Activity and Lymphedema (the PAL trial): assessing the safety of progressive strength training in breast cancer survivors. Contemp Clin Trials. 2009;30(3):233-45. http://dx.doi.org/10.1016/j.cct.2009.01.001. PMid:19171204

35. Suami H, Pan WR, Taylor Gl. Changes in the lymph structure of the upper limb after axillary dissection: radiographic and anatomica study in a human cadaver. Plast Reconstr Surg. 2007;120(4):982 91. http://dx.doi.org/10.1097/01.prs.0000277995.25009.3e. PMid:17805128

36. Gomide LB, Matheus JP, Candido dos Reis FJ. Morbidity after breast cancer treatment and physiotherapeutic performance. Int J Clin Pract. 2007;61(6):972-82. http://dx.doi.org/10.1111/j.1742 1241.2006.01152.x. PMid:17362480

37. Gashev AA, Zawieja DC. Physiology of human lymphatic contractility: a historical perspective. Lymphology. 2001;34(3):124 34. PMid: 11549124

38. Tartaglione $\mathrm{G}$, Pagan $\mathrm{M}$, Morese R, et al. Intradermal lymphoscintigraphy at rest and after exercise: a new technique for the functiona assessment of the lymphatic system in patients with lymphoedema. Nucl Med Commun. 2010;31(6):547-51. PMid:20215978.

39. McGeown JG, McHale NG, Thornbury KD. The role of externa compression and movement in lymph propulsion in the sheep hind limb. J Physiol. 1987;387(1):83-93. http://dx.doi.org/10.1113/ jphysiol.1987.sp016564. PMid:3656186

40. Bruyère F, Noël A. Lymphangiogenesis: in vitro and in vivo models. FASEB J. 2010;24(1):8-21. http://dx.doi.org/10.1096/fj.09-132852. PMid:19726757 
Correspondence Mariana Maia Freire de Oliveira Universidade Estadual de Campinas, Setor de Fisioterapia (CAISM/ UNICAMP)

Rua Alexander Fleming, 101 - Cidade Universitária CEP 13083-330 - Campinas (SP), Brazil Tel.: + 55 (19) 3527-9428

E-mail:marimfo@yahoo.com.br

Author information MMFO - PhD, physical therapist at the Physical Therapy Service, Hospital da Mulher Prof. Dr. José Aristodemo Pinotti, Centro de Atenção Integral à Saúde da Mulher (CAISM), Universidade Estadual de Campinas (UNICAMP).

MTPA - PhD, physical therapist at the Physical Therapy Service, Hospital da Mulher Prof. Dr. José Aristodemo Pinotti, Centro de Atenção Integral à Saúde da Mulher (CAISM), Universidade Estadual de Campinas (UNICAMP).

MSCG - tenured professor at the Department of Tocogynecology, School of Medical Sciences, Universidade Estadual de Campinas (UNICAMP).

Author contributions Conception and design: MMFO, MTPA, MSCG Analysis and interpretation: MMFO, MTPA

Data collection: MMFO Writing the article: MMFO, MTPA

Critical revision of the article: MSCG Final approval of the article*: MMFO, MTPA, MSCG

Statistical analysis: N/A Overall responsibility: MMFO

* All authors have read and approved of the final version of the article submitted to J Vasc Bras. 